\title{
Viral inhibitors to control the Papaya ringspot virus on Carica papaya
}

\author{
Ricardo Hernández Pérez ${ }^{1}$, Dagoberto Guillen Sanchez², Marlene Pérez \\ López ${ }^{3}$, and Enrique Casanova $\mathrm{Casio}^{4}$
}

${ }^{1}$ Agrodiagnostic Lab. (FITOALB). SA de CV. Bugambilia Street. No.9 El Mirador Puxtla. Cuautla, Morelos. México. C.P 62758.

${ }^{2}$ Autonomous University of Morelos, Superior Studies School of Xalostoc. Xalostoc, Ayala, Cuautla. Morelos CP. 62209.

${ }^{3}$ Cienfuegos University, Faculty of Agronomy. Way to Rodas km 4. Four way. Cienfuegos. Cuba. CP: 55100.

${ }^{4}$ Cienfuegos University, Study Center to Agriculture Transformation. Way to Rodas km 4. Four way. Cienfuegos. Cuba. CP: 55100.

\begin{abstract}
R. Hernández, D. Guillen, M. Pérez, and E. Casanova. 2017. Viral inhibitors to control the Papaya ringspot virus on Carica papaya. Cien. Inv. Agr. 44(3): 312-319. Few results related to the control of plant viruses have been reported successfully, and less research has been carried out under field conditions for the pathogens. The Papaya ringspot virus (PRSV) is a very challenging virus to combat and prevents achieving a high productive potential in Carica papaya due to the lack of resistant genes in commercial papaya cultivars such as red Maradol, which originated in Cuba and extends to all America and the Caribbean. In this study, the effectiveness of a new viral inhibitor (Inhibitovir), applied as a preventive and curative treatment to control PRSV was evaluated under field conditions. The results showed the possibility of using this viral inhibitor against PRSV because its effectiveness was comparable to that of the commercial antiviral (Q-2000VI). The use of Inhibitovir can prevent the damages caused by PRSV with satisfactory protection until harvest, allowing yield increases of 1.5 to 3 times. The preventive effect of Inhibitovir applications can attenuate and reduce disease symptoms, even in those plants that were infected prior to treatment. The field application of a new antiviral formulation offers a new alternative for efficient PRSV control, which can be included in integrated pest management.
\end{abstract}

Keywords: Carica papaya, papaya, papaya diseases, Q 2000VI, red Maradol, viral inhibitor.

\section{Introduction}

Papaya (Carica papaya L.), the third most economically important fruit crop, has social and economic importance in tropical and subtropi-

Received February 12, 2017. Accepted August 17, 2017

Corresponding author: santaclara57@yahoo.es cal regions. Yields were $135,700 \mathrm{t} \mathrm{ha}^{-1}$ in 2010, and production decreased to approximately $20 \mathrm{t}$ $\mathrm{ha}^{-1}$ in 2011, apparently due to the effect of viral diseases (FAO, 2011).

Viral diseases represent a major phytosanitary problem, especially those transmitted by insect vectors, such as the Papaya ringspot virus (PRSV) 
(Potyviridae, Potyvirus), which are considered the most economically important viral disease affecting papaya due to its geographical distribution in almost all papaya producing regions as well as its high virulence and high yield losses (Cabrera, 2014).

So far, the fight against PRSV has been difficult (Hernández et al., 2004). Only with a complex group of phytosanitary measures has it been possible to achieve acceptable papaya productions (Hernández et al., 2015).

For that reason, the prevention of PRSV has occurred through the use of healthy plants, physical barriers, chemical control of insect vectors and the elimination of diseased plants (Cabrera et al., 2010; Cabrera et al., 2012 and Hernández et al., 2015). However, some antivirals are currently on the market: Virus Stop (Fagro S.A., Mexico), Q 2000 VI Quimcasa, Mexico), antivirus produced by Fertinosa (Mexico) and the preventive natural antiviral (Ekologik) marketed by Bioaga Cellular Biology Lab (USA).

The main objective of this study was to evaluate the effectiveness of Inhibitovir a new viral inhibitor for the field control of PRSV in papaya cv. red Maradol.

\section{Materials and methods}

\section{Serological diagnosis}

The PRSV isolate was obtained from papaya plants in the experimental field located in (CCS) Dionisio San Roman (Cienfuegos, Cuba). Symptomatic samples of papaya leaves cv. red Maradol were analyzed for the presence of PRSV (Hernández et al. (2015). Detection and presence of PRSV in the leaf samples, was performed by a DAS-ELISA using a PathoScreen commercial kit from Agdia Inc.

\section{Molecular diagnosis}

Positive leaf samples were reanalyzed by the RTPCR reaction. Total RNA extraction from papaya leaves with visible symptoms of the virus (PRSV) was performed using a commercial RNeasy ${ }^{\circledR}$ Plant Mini Kit (Qiagen) following the protocol proposed by Qiagen (Cabrera, 2014).

\section{Transmission to test plants}

Initially, the virus isolate was used to produce artificial infection in the papaya plants located in the Experiment Station "La Colmena", CETAS, Cienfuegos University.

The first three leaves, used for (Trat. III and V), were inoculated $10 \mathrm{~d}$ before transplant. For this inoculation, diseased leaves were macerated in a solution containing a $0.01 \mathrm{M}$ sodium/potassium buffer ( $\mathrm{pH} 7.0)$ and $0.1 \%$ sodium sulfite, diluted to $1: 10(\mathrm{w} / \mathrm{v})$.

To reinforce the mechanical inoculation, plants were reinoculated using five aphids (Myzus persicae) per plant, previously fed on diseased papaya plants (Bau et al., 2003; Cruz, 2007).

\section{Antivirals}

Inhibitovir is a commercial product with viricidal action produced by Proveedora Fitozoosanitaria S.A. CV (Mexico) and registered in Cuba (Register No. 1160947) (IMPI 2010). It is composed of an analogue base (1.8\%), antiseptic $(2.0 \%)$, antioxidants $(1.0 \%)$, vitamins $(0.065 \%)$, solvent $(75.13 \%)$ and water. As a control treatment, the viricidal product Q-2000 VI (Quimcasa, Mexico) was used.

\section{Field treatments against PRSV}

Papaya seedlings were planted in east to west double rows spaced at $3.0 \times 1.5 \times 1.5 \mathrm{~m}$, with a density of 2962 plants per ha (MINAG, 2006). Treatments were distributed according to a random block design with five treatments 
and three replicates. The treatments were as follows: I. Control (untreated against the virus); II. Antiviral (Q-2000 VI), preventive application (3 $\left.\mathrm{mL} \cdot \mathrm{L}^{-1}\right)$; III. Antiviral (Q-2000 VI), healing application $\left(6 \mathrm{~mL} \cdot \mathrm{L}^{-1}\right)$; IV. Viral inhibitor (Inhibitovir), preventive application (3 $\left.\mathrm{mL} \cdot \mathrm{L}^{-1}\right)$; and $\mathrm{V}$. Viral inhibitor (Inhibitovir), healing application $\left(6 \mathrm{~mL} \cdot \mathrm{L}^{-1}\right)$. The final spray volume was $200 \mathrm{~L} \mathrm{ha}^{-1}$.

Treatments II and IV and preventive controls, were applied every $15 \mathrm{~d}$, among the first and fourth mo of transplantation. These are the plant growth stages of highest infection risk by PRSV. In total, eight applications were made, with $3 \mathrm{~mL} \cdot \mathrm{L}^{-1}$, and $200 \mathrm{~L} \cdot \mathrm{ha}^{-1}$. The spray application solution was $\mathrm{pH}$ 6.0-7.0.

In Treatments III and V (healing), the products were applied when the virus infection reached grade 1, according to the scale of damages for PRSV (Cabrera et al., 2009). Applications continued every $15 \mathrm{~d}$ for $7 \mathrm{mo}$ on infected plants using $6 \mathrm{~mL} \cdot \mathrm{L}^{-1}$ and a total volume of $200 \mathrm{~L} \cdot \mathrm{ha}^{-1}$, as recommended by the manufacturer $(\mathrm{pH} 6.0$ 7.0). Treatment I did not receive applications against viruses and was uninoculated (MINAG, 2006; Rivas-Valencia et al., 2008).

\section{Evaluations}

The severity of the damage produced by the virus was found by applying a scale ( $0-4$ degrees): 0 . No symptoms; 1. Light mosaic; 2. Filiform leaves and fruits with presence of oily spots on stems and petioles; 3. Ringspots on fruits (Hernández, 1994; Cruz et al., 2008).

\section{Percentage of virus incidence}

The virus disease incidence was determined by calculating the symptomatic plants from the total plants sampled each treatment.
The mean severity of the damage caused by the PRSV was calculated using the TownsendHeuberger formula (Cabrera, 2014).

\section{Disease severity}

$$
\operatorname{DS}(\%)=\frac{\sum(\mathrm{nv})}{\mathrm{NV}} \times 100
$$

DS $(\%)=$ disease severity in each treatment; $\sum(\mathrm{n}$. $\mathrm{v})=$ degree of infection according to the scale; $\mathrm{v}=$ number of plants per category; $\mathrm{V}=$ total number of plants screened; $\mathrm{N}=$ highest degree infection.

\section{Technical Product Efficiency (Abbott)}

$$
E f=(A-B) \div A \times 100
$$

$\mathrm{E}=$ Technical Efficiency; $\mathrm{A}=$ Number of plants infected before application; B = Number of infected plants after application.

\section{Morpho agronomic evaluations}

Two plants were selected for each plot, and the following measurements were made: height of plant $(\mathrm{cm})$, stem diameter $(\mathrm{cm}$ at $15 \mathrm{~cm}$ from the ground, and number of flower buds per plant was measured and the number of fruit sets per plant. Yields were evaluated at 9 mo after transplanting. Subsequently, non-commercial fruits were counted, following MINAG (2006) quality control specifications. The number of fruits, total weight, average fruit weight and yield were recorded.

Data were subjected to analysis of variance with the aid of the statistical package SPSS version 15.0, 2006. The data that did not fulfill the normality assumptions were applied non-parametric analysis with Kruskal-Wallis rank comparison for $\mathrm{p}<0.05$. 


\section{Results and discussion}

\section{Incidence and detection of Papaya ringspot virus}

The leaf samples analyzed were positive for ELISA-DAS serological diagnosis and the presence of PRSV was confirmed after obtaining amplification of a DNA fragment of approximately 850 base pairs (bp) by RT-PCR, as detected by other authors (Portal et al., 2006).

The incidence of PRSV increased in correspondence to the phenological stage of the papaya up to $78 \%$ of virus infection in uninoculated plots and $98 \%$ disease incidence in inoculated plots (Table 1), confirming the presence of a high inoculum pressure. Likewise, the incidence was low when the antivirals were applied, for prevention or healing, resulting in only 28 to $32 \%$ virus incidence, respectively, at 5 mo after transplanting.

These results were superior to those usually obtained when some management strategies are applied, such as the use of anti-fouling meshes in nurseries, which only prevents the onset of infection by $90 \mathrm{~d}$ and where up to $100 \%$ incidence of PRSV appears at $105 \mathrm{~d}$ after transplanting (Cabrera et al, 2012; Cabrera, 2014).

\section{Severity of Papaya ringspot virus}

The applications of both antiviral products were able to attenuate the severity produced by the PRSV up to $160 \mathrm{~d}$ (Figure 1). The highest number of plants with (grade 1) of the disease were present when treatments were applied preventively or healingly.

While the control plants differed significantly from these treatments, with severity greater than grade 2 foliar tissue regeneration was impossible given the appearance of the filiform leaf symptoms, corroborating previous results with virus inhibitors or base analogs in culture media for virus removal (Fallis and Smith, 1989; Hernández et al., 2015).

The viral inhibitor applications made during the cycle of papaya production up to 5 mo involved a significant attenuation of symptoms and damage caused by PRSV on cv. red Maradol (Figure 2).

Some authors have reported that severity of PRSV can be reduced up to $30 \%$ when seedlings are protected in nurseries with anti-aphid mesh (Cabrera et al, 2012).

The effect of the (PRSV) can be evident, by oily spots on the stems, even before producing fruit

Table 1. Percentage of Papaya ringspot virus (PRSV) for each treatment after antiviral (Q 2000 VI) and viral inhibitor (Inhibitovir) were applied on papaya cv. red Maradol.

\begin{tabular}{lcccccc}
\hline & \multicolumn{3}{c}{ Inoculated plants $\%$} & \multicolumn{3}{c}{ Uninoculated plants \% } \\
\cline { 2 - 7 } Treatments & $\begin{array}{c}\text { Observ } \\
20 \mathrm{dat}\end{array}$ & $\begin{array}{c}\text { Observ } \\
60 \mathrm{dat}\end{array}$ & $\begin{array}{c}\text { Observ } 160 \\
\text { dat }\end{array}$ & $\begin{array}{c}\text { Observ } 20 \\
\text { dat }\end{array}$ & $\begin{array}{c}\text { Observ } \\
60 \text { dat }\end{array}$ & $\begin{array}{c}\text { Observ } 160 \\
\text { dat }\end{array}$ \\
\hline Preventive (Q-2000 VI). & $35,5 \mathrm{a}^{\dagger}$ & $28,7 \mathrm{a}^{\dagger}$ & $31,0 \mathrm{a}^{\dagger}$ & $36,5 \mathrm{a}^{\dagger}$ & $26,5 \mathrm{a}^{\dagger}$ & $28 \mathrm{a}^{\dagger}$ \\
Healing (Q-2000 VI). & $38 \mathrm{~b}$ & $38,1 \mathrm{~b}$ & $32,1 \mathrm{a}$ & $39,0 \mathrm{a}$ & $31,2 \mathrm{~b}$ & $32 \mathrm{~b}$ \\
Preventive Inhibitor & $33 \mathrm{a}$ & $28,7 \mathrm{a}$ & $32,1 \mathrm{a}$ & $36,5 \mathrm{a}$ & $34,3 \mathrm{~b}$ & $30 \mathrm{~b}$ \\
Healing Inhibitor & $38 \mathrm{~b}$ & $47,2 \mathrm{c}$ & $26,7 \mathrm{a}$ & $36,5 \mathrm{a}$ & $38,3 \mathrm{~b}$ & $32 \mathrm{~b}$ \\
Control & $45,5 \mathrm{c}$ & $47,4 \mathrm{c}$ & $98,0 \mathrm{c}$ & $41,5 \mathrm{c}$ & $59,6 \mathrm{c}$ & $78 \mathrm{c}$ \\
P-value (chi ${ }^{2}$ ) & 0,0874 & 0,0044 & 0,0 & 0,2421 & 0,0 & 0,0 \\
Kruskal-Wallis test & 7.9692 & 14.2931 & 45.1876 & 5.4815 & 31.9506 & 59.5776 \\
\hline
\end{tabular}

${ }^{\dagger}$ The same letters in a column indicate no significant difference according to the Kruskal-Wallis test and P-value $\left(\mathrm{chi}^{2}\right)(<0.05 \%)$. dat (d after transplantation). 


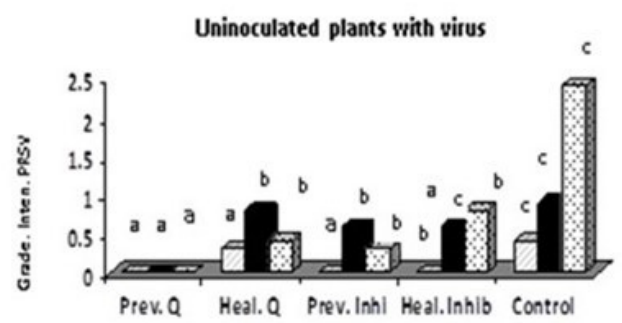

Q20TD 60 TD O160T.D
Inoculated plants with virus

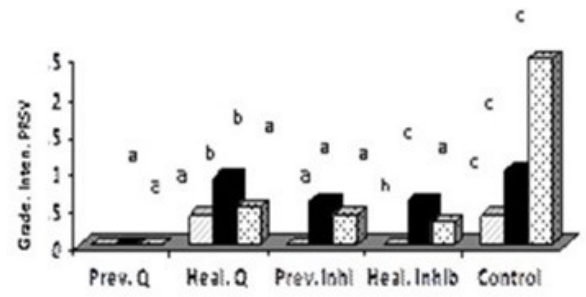

D20TD $\quad 60 \mathrm{TD} \quad 0160 \mathrm{TD}$

Figure 1. Damage intensity on papaya plants inoculated and uninoculated with PRSV during observations, at 20, 60 and $160 \mathrm{~d}$ after transplantation (20,60 and $160 \mathrm{TD}$ ). Value in scale damage obtained after applications of inhibitor and antiviral, healing (Heal.) and preventive (Prev.). Bars with the same letter do not differ for $\mathrm{P}<0.05$ according to the Kruskal-Wallis test.

rings and by an inclination of the petioles towards the soil that may reduce the photosynthetic activity of the leaves (Figure 2a). However, when the plants recovered, (Figure 2b), a change of normal green color leaves and floral primordium increased number was observed in plants treated.

This promotes an increase in productive potential even in plants infected prior to treatment (Figure 2c), suggesting a decrease in viral replication after applying the viral inhibitor. Similar results with formulations containing ribavirin have been reported in virus control, by inhibiting the viral messenger RNA guanylation process that stimulates the natural defenses of plants (Jean-Claude et al., 2005). Nevertheless, further research is needed to prove this hypothesis.

The results obtained with Inhibitovir, corroborated the results of Fangjun (2007) when applying an antiviral nutrient solution that increased the resistance of plants to diseases. Complementary to the increase in antioxidant activity, as has been inferred by Rangel et al. (2010), when salicylic acid (AS) is applied, it reduces viral RNA synthesis.
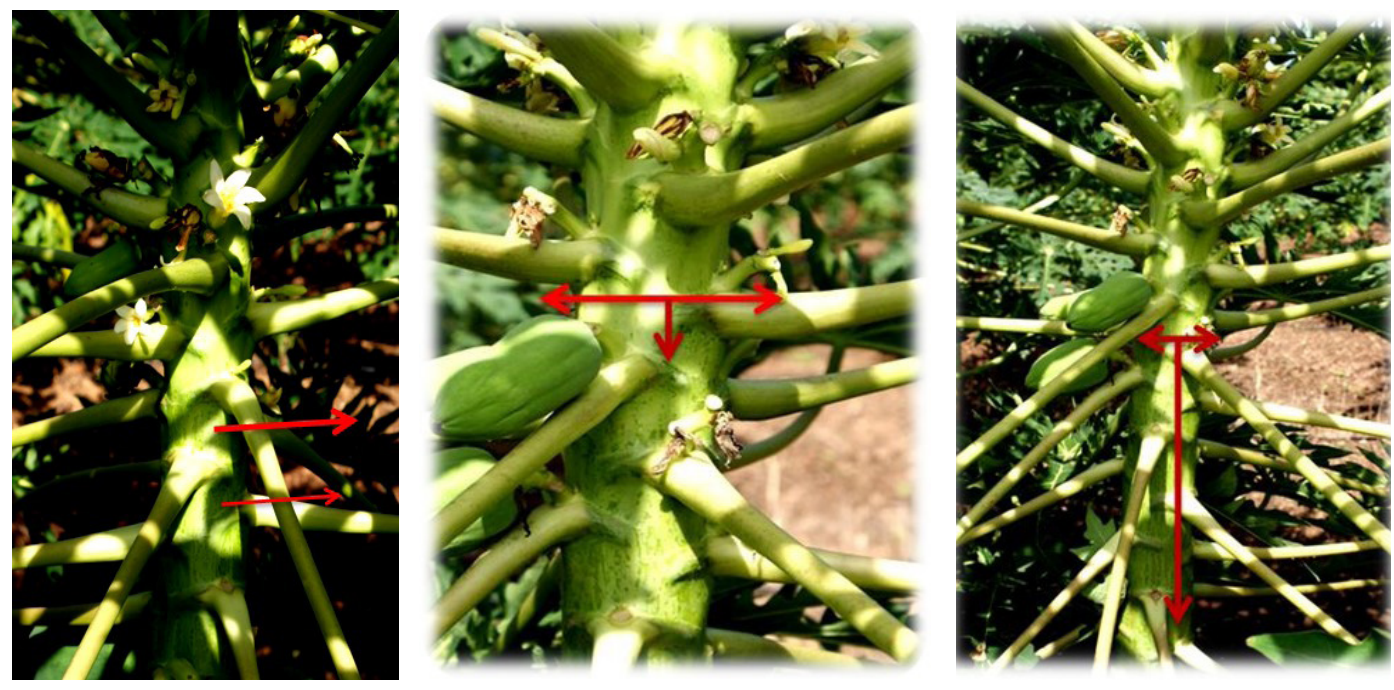

Figure 2. Damage delimitation in plants infected by the Papaya ringspot virus (PRSV) after 5 mo of transplantation and effect of antiviral products applications. a) Control plant on the left, showed few fructification and petioles leaning towards the ground. Right b) plants treated with Inhibitovir showing recovery of flowering. c) Delimitation of the affected area in plant with attenuation of damages, disappearance of oil spots on the stem and upward petioles. 
The biological effectiveness evaluated in this study was $57.1 \%$ effectiveness after Inhibitovir applications and $71.4 \%$ of effectiveness after Q-2000VI applications. These results were acceptable in relation to those reported previously (Qinfu et al., 2003), indicating up to $80 \%$ effectiveness against Cucumber mosaic virus (CMV) and Tobacco mosaic virus (TMV), after having used an analogue product of similar base but under greenhouse conditions.

These results are interesting because they were obtained under field conditions with a new virus inhibitor formulated against the potyvirus (PRSV) in papaya, representing an important step forward in the improvement of the control management of this disease.

\section{Morpho agronomic parameters}

Plant height and stem diameter, reached $2.29 \mathrm{~m}$ and $1.51 \mathrm{~cm}$, respectively, when the antiviral inhibitor was used but differences with the control treatment (Treatment I) were not significant. The emission of flowers per mo was increased considerably in the treated plants up to $230 \mathrm{~d}$. This confirmed the information reported by Seeds Caribbean (2006) about the agronomic parameters of cv. red Maradol, which is why the crop was not affected in its growth and development without showing phytotoxic effects.

The PRSV produced a reduction in the number of fruits in the untreated plants, while in the plants treated with Q-2000 VI and Inhibitovir, similar amounts of fruits were obtained without significant differences among them but with significant difference from the control performance (Figure 3).

The evaluation of the potential yield at $240 \mathrm{~d}$ after transplantation showed an increase in fruit quantity, fruit weight and productive potential (ha${ }^{1}$ ), evidently, produced by the antiviral products applied against the PRSV.

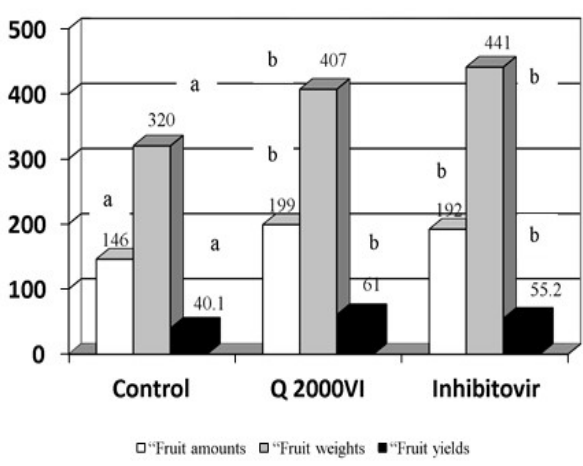

Figure 3. Effect of virus treatments on fruit quantity, fruit weight and productive potential $\left(\mathrm{t} \cdot \mathrm{ha}^{-1}\right)$ of papaya $\mathrm{cv}$. Red Maradol. Bars with the same letter do not differ for $\mathrm{P}<0.05$ according to the Kruskal-Wallis test.

Undoubtedly, a reduction of the symptoms caused by this virus, allowed chloroplasts to function better, reducing losses in yield and chlorophyll content, according to some potyvirus information (Cabrera et al., 2009).

The relationship between total weight and yield showed the best value when applying the Q-2000 VI with an average of $61.0 \mathrm{t}^{\cdot \mathrm{ha}^{-1}}$, while Inhibitovir yielded $55.2 \mathrm{t} \cdot \mathrm{ha}^{-1}$ without significant differences between them but surpassing the control, which yielded only $40.1 \mathrm{t} \cdot \mathrm{ha}^{-1}$. This corroborated the idea of using this viral inhibitor as an alternative to counteract the PRSV effect along with integrated pest management (IPM) in sustainable agriculture. This could improve the yields obtained in papaya cv. Red Maradol, delay viral infection and reduce the symptoms severity, allowing greater production of fruit and therefore increased yields over 50 t·ha-1 (Hernández et al., 2015).

The main conclusions are as follows. The Inhibitovir applications, the preventive ones in particular, at a rate of $3 \mathrm{~mL} \cdot \mathrm{L}^{-1}$ produced considerable attenuation of PRSV symptoms in papaya plants, with a relatively low incidence and severity, without reaching irreversible damages such as filiform leaves in the field. The biweekly treatments with Inhibitovir and Q 2000 VI increased yields between 1.5-3 times above the control. 


\section{Resumen}

\section{R. Hernández, D. Guillen, M. Pérez, y E. Casanova. 2017 Inhibidor viral para el control} del Virus de la mancha anular (PRSV) en Carica papaya L. Cien. Inv. Agr. 44(3): 312-319. Pocos resultados en el control de virus en las plantas han sido informados con éxito y llevado al campo en el manejo de estos patógenos. Papaya ringspot virus (PRSV) es un desafío que impide alcanzar un alto potencial productivo en este cultivo, debido a la falta de genes de resistencia en variedades comerciales de papaya como rojo Maradol, originario de Cuba y extendido a toda América y el Caribe. En esta investigación se evaluó la respuesta del nuevo inhibidor viral (Inhibitovir) en forma preventiva y curativa para controlar la PRSV en condiciones de campo. Los resultados muestran la posibilidad de utilizar este inhibidor viral cuando se comparó con un antiviral comercial (Q-2000VI), ambos empleados para controlar PRSV. El uso de este producto puede prevenir los daños causados por la enfermedad resultado una mejor condición fitosanitaria de la plantación hasta la cosecha, tiempo suficiente para llegar a obtener un alto rendimiento entre 1,5 a 3 veces. El efecto preventivo de las aplicaciones de inhibidores virales, puede atenuar los síntomas de la enfermedad o producir menos síntomas en plantas enfermas, incluso llegar a florecer y fructificar. La aplicación en campo del formulado, ofrece una nueva alternativa para un control más eficaz de PRSV, el cual puede incluirse en un Manejo Integrado de Plagas.

Palabras clave: Inhibidor viral, maradol roja, papaya (Carica papaya L.), Q 2000VI.

\section{References}

Bau, H.J., Y.H. Cheng, T.A. Yu, J.S. Yang, and S.D. Yeh. 2003. Broad-spectrum resistance to different geographic strains of Papaya ringspot virus in coat protein gene transgenic papaya. Phytopathology 93:112-120.

Cabrera, M.D., M.M. Cruz, and O. Portal. 2010. Efecto de la temperatura en la virulencia del virus de la mancha anular de la papaya (PRSV-p). Fitosanidad. 14:123-125.

Cabrera, M.D., M.R. Sosa, V.O. Portal, A.Y. Alburquerque, R.J.E. González, and P.R. Hernández. 2009. Alterations induced by papaya ringspot potyvirus on chlorophyll content in papaya (Carica papaya L.) leaves. Fitosanidad 13:125-126.

Cabrera M.D., H.D. García, A.M.W. Caballero, M.P.L. García, and V.O. Portal. 2012. Manejo de la mancha anular de la papaya mediante el uso de malla antiáfidos en viveros de Carica papaya $\mathrm{L}$. var. Maradol roja. Fitosanidad, 15:241-244.

Cabrera, M.D. 2014. Caracterización biológica y molecular del Virus de la mancha anular de la papaya, epifitiología y manejo de la enfermedad en C. papaya L. var. Maradol roja en Cuba. Ph.D. diss., Universidad Central de Las Villas, Cuba.

Cruz, M. 2007. Evaluación de la respuesta a la inoculación con el Virus de la Mancha Anular de la Papaya de plantas transgénicas de papaya (Carica papaya L.) variedad Maradol roja en condiciones semicontroladas. Master diss., Universidad Central de Las Villas, Cuba.

Fallis, R. and R. Smith. 1989. (Reg Patent: NZ213370A). Methods of threating viral infections of selected trees and field crop using ribavirin. USA.

Fangjun, D. 2007. Antiviral nutrient solution for plants. Patent Reg Int: CO5G3/00. Publication: CN101050145. USA.

FAO. 2011. Anuario de Producción. Organización de las Naciones Unidas para la Agricultura y la Alimentación (FAO). Roma, Italia. 50:187-190.

Hernández C.E., J. Villanueva, R. MosquedaVázquez, and J.A. Mora-Aguilera. 2004. Efecto de la erradicación de plantas enfermas por el PRSV-P en un Sistema de Manejo Integrado del 
Papayo (C. papaya L.) en Veracruz, México. R. Mex. Fitop. 2:383-387.

Hernández C.E, N.A. Damián, A.A. Mora, J.J. Villanueva, D.A. Vargas, and A.D. Palemón. 2015. Incidence of the papaya ringspot virus (PRSV-p) and management in the state of Guerrero, Mexico. Capt. 7. Tropical Fruits. Editors: S. Dimitrov Todrov and I. Vitanova I. Nova Science Publish. IMPI. 2010. Marca y diseño (Inhibitovir). Registro No. 1160947: Propiedad Industrial (IMPI). México. http://siga.impi.gob.mx/newSIGA/content/common/principal.jsf

Jean-Claude, Y., M. Rozenn, K. Serge, and F. Bernard. 2005. Agent for stimulating the natural defenses of plants, useful as antiviral, antibacterial, antifungal and insecticide, comprise curdian sulfate. Patent Reg Int. AO1N63/02; AO1N43/16; AO1N43/02 (IPC1-7):AO1N63/02. Publication. FR2865350.

MINAG. 2006. Aspectos Técnicos para la producción de la Fruta Bomba (Carica papaya L.). Instituto de Viandas Tropicales. INIVIT. Villa Clara. Cuba.
Portal, O., D. Cabrera, A. Sánchez, A.L. Darías, J.E. Gonzáles, and R. Gómez. 2006. Molecular characterization of two Cuban isolates of the Papaya ringspot virus by means of coat protein analysis. Commun Agric Appl Biol Sci. 71:1203-1205.

Qinfu, ZH., AN. Derong, and Chi MA. 2003. An agent for the inhibition and control of plant viruses. Patent Reg Int: AO1N43/653; AO1N43/64; (IPC 1-7):AO1N43/647. Publication: WO03063591.

Quimcasa, S.A. 2008. Inhibidor viral Q-2000 VI.

Rangel G.S; E.M. Castro, E.P. Beltran, O. Reyes de la Cruz, and E.P. García. 2010. El ácido salicílico y su participación en la resistencia a patógenos en plantas. Rev. Cienc. Biológico Agrop. 12:90-95.

Rivas-Valencia, P., G. Mora-Aguilera, D. Téliz-Ortíz, and A. Mora-Aguilera. 2008. Evaluación de barreas vegetales em el manejo integrado de la mancha anular del papayo Michoacán, Mexico. Summa Phytopathol 34: 318-320.

Seeds Caribbean. 2006. Tecnología de la fruta Bomba. http://www.semilladelcaribe.com.mx/paginas/5-6.htm (accessed 12 Jun. 2006). 